\title{
EREBEA
}

Revista de Humanidades

y Ciencias Sociales

Núm. 1 (2011), pp. 21-40

ISSN: 0214-0691

\section{AFFIRMABANT AUTEM PRAEFATI, COLUMBAM AD AURES \\ SERVI DEI AMBROSII SE VIDISSE, DUM PRAEDICABAT \\ Holy Spirit and the Medieval Preaching}

\author{
Jussi Hanska \\ University of Tampere
}

RESUMEN

El artículo analiza el papel del Espíritu Santo en la predicación medieval, tal como lo percibieron los contemporáneos. Tras una introducción que esboza brevemente cómo se veía la acción del Espíritu en la predicación durante la época de la iglesia primitiva, el artículo se divide en dos partes principales, una primera que analiza la autopercepción de los predicadores y otra que trata de los auditorios. El autor propone que los predicadores entendían la presencia del Espíritu Santo como una evidencia inmediata, en tanto los auditorios tendían a percibir esa influencia sólo cuando se trataba de los más carismáticos predicadores.

Palabras Clave

Espiritu Santo, Predicación, Edad Media, Carisma, Inspiración divina.

Fecha de recepción: 15 de febrero de 2011

Fecha de aceptación: 11 de marzo de 2011

\section{ABSTRACT}

This article analyses the role of the Holy Spirit in medieval preaching as the contemporaries saw it. After an introduction that briefly outlines how the Holy Spirit's action was seen to affect into the preaching during the Early Church, the article is divided into two major parts. The first one analyses the self perception of the preachers and the second one deals with the audiences. The article proposes that preachers undertook the presence of the Holy Spirit as an inmediate evidence whereas the audiences tended to see its influence only in connection with the most charismatic preachers.

\section{KeYWORDS}

Holy Spirit, Preaching, Middle Ages, Charisima, Divine inspiration. 



\section{INTRODUCTION}

This article will study the role and influence of the Holy Spirit within medieval preaching, mostly during the great preaching revival of the thirteenth century. ${ }^{1} \mathrm{It}$ is not my intention to take any theological position, but what I am analysing are beliefs and perceptions of the medieval preachers and their audiences, verity and theological nature of such believes do not concern us here. ${ }^{2}$

Before we can seriously study the role of the Holy Spirit in medieval preaching, it is necessary to understand the particular nature of preaching as a means of communication. To give a sermon does not mean to speak in the ordinary sense of the word. There is a major difference between a sermon and a speech. According to Jean Longère to preach is to make a public discourse that is based on Divine revelation, belonging to an organised society, with object of giving birth or developing faith and the religious knowledge, and in strict report with conversion or spiritual progress of the audiences. ${ }^{3}$ Thus for Longère in order to be a sermon, a speech must be given by a person belonging to a religious community (a church), it must be based on some sort of Divine revelation, in Christian case on the holy script, and its scope must be religious education and nutrition of faith, or at least conversion.

Beverly Maine Kienzle defines the sermon very much like Longère: 'The sermon is essentially an oral discourse, spoken in the voice of a preacher who addresses an audience, to instruct and exhort them, on a topic concerned with faith and morals and based on a sacred text.' The only important difference is the bigger emphasis given for the preacher as a sort of medium. Kienzle clarifies further the role of the preacher in this communication system that is called preaching: 'While the sermon emanates from the preacher, it also represents a chain of communication with three parts: divine inspiration or revelation, the preacher, and the audience. While Jewish preachers did not "ordinarily" claim that God had called them to speak, medieval Christian preachers viewed themselves as the os Domini, the mouth of the Lord,

1 On the thirteenth-century preaching revival, see David d'Avray, The Preaching of the Friars. Sermons diffused from Paris before 1300 (Oxford, 1985), pp. 13-28.

2 For a short introduction to the early Christian and Medieval theology on Holy Spirit, see R. Hauber, 'Heilige Geist' Lexikon des Mittelalters IV. Erzkanzler bis Hiddensee (Munich, 2003), cols. 2022-2024.

3 Jean Longère, La prédication médiévale (Paris, 1983), p. 12. 
reflecting the conviction that as interpreters of God's word their authority derived from higher source.'

What then could have been this 'higher source'? A self evident solution is the Church that authorised preachers to their work and set the limits on who and under what conditions was allowed to preach. However, this legalistic solution does not really cover the whole issue. The fact that a sermon was based on the Divine revelation and Divine inspiration meant that it was not mere another public speech, but there was Divine presence in the very act of preaching. It was not a sacrament, but nor was it just an ordinary speech. The holiness of the preaching situation gave extra authority to the words of the preacher.

Where from did, or indeed does, this holiness emanate to the sermon act? If one looks at the earliest history of the Christian church (letting aside the case of the preaching of Jesus Christ himself), the answer is rather obvious. The Acts of Apostles describe how the apostles were filled with the Holy Spirit in the first Pentecost after the death of Jesus, and they started to speak in languages and preach to the people (Acts 2:1-41). During the apostolic period the first Christian churches were founded by the apostles and prophets who, at least in Saint Paul's opinion were working under the direct influence of the Holy Spirit. ${ }^{5}$

The New Testament and the Patristic writings are filled with passages where the ability to teach is defined as one of the Xápíorá or gifts of the Holy Spirit. When the primitive Church developed into an Church institution the presence of the gifts of the Holy Spirit declined. Whereas the second century authors still testify of the faith to the miraculous gifts of the Holy Spirit in the Church, already Origen $(\dagger 254)$ wrote that the signs of the Spirit that had been numerous in time of Jesus and Apostles, had now become rare. ${ }^{6}$ The self-appointed prophets to whom the Spirit had given ability to foretell the future vanished altogether from the Church. They were replaced with hierarchical church structure with its

4 Beverly Mayne Kienzle, 'Introduction', in The Sermon. Typologie des sources du Moyen Âge Occidental, fasc. 81-83. Directed by Beverly Mayne Kienzle (Turnhout, 2000). pp. 151-153.

5 W.H.C. Friend, The Rise of Christianity (Philadelphia, 1985, $1^{\text {st }}$ published in 1984), pp. 106107, 140.

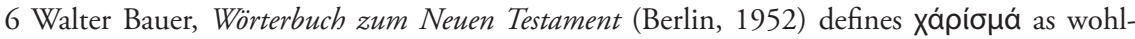
wollend gespendete Gabe or Gnadenschenk.; A Patristic Greek Lexicon. Edited by G.W.H. Lampe (Oxford, 1961) defines it as: spiritual gift, and specifies that it can originate either from God, Christ or Holy Spirit. From the point of this article the best definition and explanation is provided by A. Monaci Castagnano, 'Carismi', Dizionario patristico e di antichità christiane. Diretto da Angelo

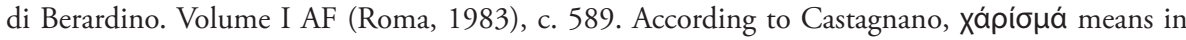
general sense gift, and in particular Divine grace. In the writings of saint Paul, the word xápíopá is used to mean gifts of Holy Spirit that can be distinguished in two categories. The first consists of those gifts that are not connected to any particular office in the Christian community. They are speaking with languages, performing miracles, and healing. The second category consists of those Divine graces that allow one to rule, assist and teach in the community. The gift of wisdom and eloquence needed to preaching well falls into the latter category. 
appointed officials, the priests and bishops. The Holy Spirit ceased to influence directly on the election of the preachers, or, at least, Its openly manifest influence was not anymore condition sine qua non one could not obtain licence to preach.

However, as will be shown in this article, it was nevertheless perceived that the influence of the Holy Spirit continued within the medieval Church and especially within the act of preaching. While during the middle ages it was possible to become a preacher without direct and visible intervention of the Holy Spirit, Its presence did not vanish from the preaching, or indeed, from the minds of the audiences and self-perception of the preachers.

\section{The Holy Spirit and the Preacher}

Having established the fact that the Holy Spirit was considered to be routinely present at the orthodox sermons, we may now move on to the cases where Spirit's presence was particularly observed either by the preacher himself or by the audiences. We start with the preachers themselves, and ask how did they perceive the presence of the Holy Spirit in the preaching.

One of the most interesting treatments of this problem is included in the synodal sermon by Federico Visconti, archbishop of Pisa. This sermon was delivered in 23 May 1260 for the clerical audience, that is, an audience consisting of the preachers. Fittingly for the liturgical occasion Federico Visconti chose to start his sermon with a prothema 'Dominus dabit verbum evangelizantibus virtute multa' (Ps. 67:12). ${ }^{7}$

After pronouncing the prothema the preacher continues: 'On the above presented authority by David the most excellent of the prophets, or more likely, the Holy Spirit through his mouth, exhorts all those who are negligent through fear and weakness to preach the word of God, giving them strength and courage so that they can in all security go out and preach, for it promises that God will concede them the grace of speaking with utility. ${ }^{8}$ Thus Federico is presenting David as prophet and preacher who through his Psalms speaks ('David, immo Spiritus Sanctus per os eius...') to the audience of the priests that were gathered together in the synod to exhort them to preach courageously with the help of God. This passage is not the only case where Federico Visconti claimed that the Holy Spirit spoke with mouth of the authorities. The other case is included in the sermon In reconciliatione cuiusdam heretici addressed also to the Pisan clergy. ${ }^{9}$

7 The sermon is edited by Nicole Bériou; Les sermons et la visite pastorale de Federico Visconti archevèque de Pise (1253-1277). Sous la direction du Nicole Bériou (Sources et documents d'histoire du Moyen Âge publies par l'École française de Rome 3 (Rome, 2001), pp. 345-361.

8 Federico Visconti, Sermo in Pentecosten in synodo, p. 346.

9 Federico Visconti, Sermo in Reconciliatione cuiusdam heretici. In Les sermons et la visite pastorale de Federico Visconti archevèque de Pise (1253-1277). Sous la direction du Nicole Bériou (Sources et documents d'histoire du Moyen Âge publies par l'École française de Rome 3 (Rome, 2001), p. 
Below Federico continues his sermon from the first part of division: 'Thus he says: "The Lord shall give the word to them that preach good tidings." And surely, just like the Holy Spirit speaks in the Old Testament through the prophet, the same thing is said by Jesus Christ in the New Testament, Mt. 10 (10:19): "For it shall be given you in that hour", that is of the preaching, "what to speak." On the following passages Federico clarifies further how the preacher will be given wisdom in what he preaches and knowledge of how to present this message eloquently because 'one of those without the other is not enough for those who want to be useful in their preaching. ${ }^{10}$

Then follows the most important passage where Federico explains how God in practise gives these promised abilities, namely wisdom and eloquence, to the preachers. He says: 'In this way, therefore you should go out without trembling and full of confidence and preach His word, and more so because it is not us that speak, "but the" the Holy "Spirit that speaketh in us." Mt. 10(:20). But how are we to understand this? Note that man is like a musical instrument, namely string of the guitar or lyre. If it is not in tuned, it emits a sound that is bad and out of tune, but if it is tuned by a master, it lets out loud, sweet and melodic sound. So it is with the preacher, if he is tuned by the Holy Spirit, his voice is sweet for the ears of the audiences, like it is said: "let thy voice sound in our ears: for thy voice is sweet, and thy face comely. "Cant. 2(:14).'11

Thus we see that at least for Federico Visconti, the presence of the Holy Spirit was very much real in preaching. In his case we may state against the above quoted opinion of Beverly Maine Kienzle that the preacher actually did claim that it was God that called him, and not just him, but all the preachers to speak. To be effective, the sermon had to be inspired, or as he put it, the preacher had to be tuned by the Holy Spirit.

Therefore, it is only fitting that Federico Visconti concludes the here analysed prothema with direct invocation of the Holy Spirit before he moves into the actual thema and the division of his sermon: 'And thus, whatever He wants to say through us, that is, through you and me, who intend preach here, let him tune us in sucha manner that we can preach the word of God in useful manner. Let us all invoke Him with devotion and humility, and say: "Veni, Sancte Spiritus, reple tuorum corda fidelium et tui amoris in nobis ignem accende." Amen. ${ }^{12}$

990. 'Revelabunt celi etc. Quamquam beatissimus Gregorius, sive Spiritus sanctus per os eius hanc auctoritatem duobus modis exponat, prout in libro Moralium continetur...'

10 Federico Visconti, Sermo in Pentecosten in synodo, p. 347.

11 Federico Visconti, Sermo in Pentecosten in synodo, p. 348.

12 Federico Visconti, Sermo in Pentecosten in synodo, p. 349. The Latin is left in quotation because it is Antiphona in vesperis Pentecosten. 
The self perception of Federico Visconti as a preacher is more important than just the testimony of one single preacher. It needs to be taken into account that Federico was addressing to an audience consisting of priests. He was not speaking to the lay audience and therefore, he did not need to give extra credibility for his speech or underline the importance of the preaching. He was addressing to other preachers and more over, in connection of synod where one would talk shop. Therefore, it seems highly likely that Federico was expounding his real sentiments on the preaching. Furthermore, there are other preachers who, when dealing with their profession, also connect Holy Spirit to the preaching.

Italian Dominican Jacopo da Varazze writes about the role of the Holy Spirit in teaching in his third sermon for the Pentecost. Jacopo divides his sermon in four parts. The last one is about how 'Spiritus Sanctus est instructor noster'. Jacopo does not use the words preach or preacher, but instead the words teach and doctor. However, from the context it is obvious that it is moral teaching he is referring to, and hence teaching can be here read as synonymous to preaching. Jacopo writes:

'Therefore, if a doctor teaches well and makes [spiritual] profit, the merit is not of the doctor, but of the Holy Spirit. This is shown by Saint Bernard [of Clairvaux] in his commentary on Song of Songs with three examples. The first one is that waters do not run straight from the fountain to the garden, but through canal or aqueduct. If then, virtues spring up in the garden of the audiences, it is not the merit of the canal, but of the fountain. Of this fountain it is said in the Song of Songs 4[:15]: "The fountain of the gardens, the well of living waters etc."13

The other two examples drawn from Bernard's commentary follow the same line and do not need to be reproduced here. Jacopo da Varazze's general argument is clear. All the useful information coming from the mouth of a teacher or preacher originates from the inspiration of the Holy Spirit who is the fountain from which water of useful doctrine or sermon flows. A preacher or teacher is merely canal or aqueduct through which this water runs. It is easy to see how close this argument is to the above quoted passages from the sermon of Federico Visconti. ${ }^{14}$ Jacopo

13 Jacopo da Varazze, Sermones de tempore. Sermo tertius in pentecosten (Lyon, post 1500), f. k6v. 'Non est ergo attribuendum doctori sed Spiritu Sancto, si aliquando quis bene doceat vel fructum faciat. Quod ostendit Bernardus super Canticam triplici exemplo. Primum est, quia aqua non fluit a fonte ad hortos, sed per canalem sive aqueductum. So igitur in horto auditorum fiat germinatio virtutum, non est gloria canalis sed fontis. De quo fonte dicitur Cant. 4: "Fons hortorum, pureus aquarum viventium etc."'

14 Another point of comparison is Bonaventure's discussion on the Holy Spirit as a teacher found in his sermon on the fourth Sunday after Easter; Sancti Bonaventurae Sermones dominicales. Studio et cura Iacobi Guidi Bougerol. Bibliotheca Franciscana Scholastica Medii Aevi 28 (Grottaferrata, 1977), p. 310. 'Secundo venit ut magister totius sapientiae propter instructionem utilis 
da Varazze was one of the most important preachers of his time, and certainly the most important writer of the model sermon collections. His Sunday sermon collection in which the above quoted sermon is to be found, is the most widely copied medieval sermon collection. It survives in hundreds of manuscripts and in considerable number of early incunabula editions.

The Polish Dominican preacher Peregrinus Oppeln compared Dominican martyr saint Pietro da Verona ( $† 1252)$ to Jesus. He wrote that Pietro resembled Jesus in three respects, he was preacher, virgin, and martyr just like Jesus had been. Peregrinus starts to expound the preacher part of the distinction by stating: "Firstly then he was a preacher. For he was chosen into this profession by the Holy Spirit." This is proven by the fact that Pietro started to preach at the age of seven to convert his heretic father. ${ }^{15}$ The story of the seven year old Pietro preaching to his heretic father was taken from Jacopo da Varazze's Legenda aurea, but the statement that Pietro was chosen by the Holy Spirit to be a preacher was Peregrinus' own interpretation of the story. ${ }^{16}$

Here the story itself, or whether we think that Pietro indeed started his anti heretic preaching at the age of seven is not important. What is important is that seasoned preacher and author of one of the true best-seller model sermon collections of the early fourteenth century, Peregrinus de Oppeln took the view that it was the Holy Spirit who chose Pietro to the profession of preacher. Clearly, Pietro da Verona was an exceptional preacher, and the fact that his preacher's vocation could have been a result of direct intervention of the Holy Spirit cannot be taken to prove that such was the case with all the preachers. However, what Peregrinus' text seems to confirm is that to gain exceptional results, a preacher needed to have the Holy Spirit as his collaborator. Otherwise he could only be a rank and file preacher, maybe even so bad that his preaching would, borrowing the metaphor of Federico Visconti, sound like out of tune musical instrument.

Perhaps the most famous medieval preacher Bernardino da Siena commented also briefly the role of the Holy Spirit in a sermon he preached on 1 September in his hometown Siena. According to reportator Bernardino said speaking about good things God makes people to say and do: 'And also, explaining better the good deeds that happen through our saying or doing, and how these do not originate from us but from God he [i.e. Bernardino] said: "Non enim uos estis qui loquimini, sed spiritus Patris uestri qui loquitur in uobis." And this is said even more of us preachers when we are preaching the Gospel of truth, than of any

doctrinae. Ipse enim est fontale principium omnis scientiae et spiritualis doctrinae christianae sive propheticae, sive apostolicae, secundum utramque legem.'

15 Peregrinus de Oppeln, Sermo in festo beati Petri martyris. In Peregrini de Opole Sermones de tempore et de sanctis. Ed. Richardus Tatarzyński (Warszawa, 1997), p. 579.

16 Iacopo da Varazze, Legenda aurea. Edizione critica a cura di Giovanni Paolo Maggioni. Tomo I (Firenze, 1998), pp. 421-422. 
other people. "For it is not you that speak, but the Spirit of your Father that speaketh in you."' 17

Here Bernardino was expounding the passage of Matthew 20:10 stating that the good words and deeds people sometimes do are not of their own merit, but they are to be attributed to the Spirit of God the Father. For medieval audiences, and for that matter, for a modern theologian, the Spirit of Father would selfevidently mean the Holy Spirit. Bernardino is saying that even more than to any other good deeds, this passage of Matthew must be understood to refer to the sermons of the preachers.

These examples, taken from the sermons of famous and influential preachers and writers of preaching materials, should suffice to prove that many preachers actually perceived the preaching situation so that they were either only transmitters between God and the audiences, or at least that there was a strong presence of the Holy Spirit in the act of preaching. Furthermore, it seems clear that many preachers also believed that the Holy Spirit was influential in providing future preachers with the skills and eloquence they needed to carry out their mission.

The firm belief into the role of the Holy Spirit was also reflected in the architecture of the preaching. A good example of this is the renaissance (or, depending on the point of view late medieval) pulpit of Santa Maria Novella in Florence. The pulpit is topped with wooden tester, painted blue within which a white dove is set in a circle of clouds and light rays. Nirita Debby claims that 'The holy dove appearing above the head of the preacher in the Santa Maria Novella pulpit was a visual reinforcement of the preacher's claim that it was not his voice being heard but that of the Holy Spirit.' ${ }^{\text {'18 }}$

The snow white dove was the traditional symbol of the Holy Spirit in Christian art. This iconographic motive originates from the passage of the Gospel according to Saint Mark where John the Baptist baptizes Jesus (Mk. 1:10): 'And forthwith coming up out of he water, he saw the heavens opened, and the Spirit as a dove descending, and remaining on him.' It's first appearances took place already during the late antiquity. There are sarcophagi with reliefs depicting the above mentioned baptism scene. ${ }^{19}$

17 Bernardino da Siena, Prediche volgari sul Campo di Siena 1427. Volume primo prediche IXXV. A cura di Carlo Delcorno (Milano, 1989), p. 485. Here I have translated in English the parts of the text that were written in Italian, and left those parts that were written in Latin as they stand to better reflect the nature of the original reportatio. For two more examples of famous fifteenthcentury preacher's reflecting Divine influence in their preaching, see Nirith Ben-Aryeh Debby, The Renaissance Pulpit: Art and Preaching in Italy 1400-1550 (Turnhout, 2007), p. 77.

18 Nirith Ben-Aryeh Debby, The Renaissance Pulpit, p. 77.

19 Gertrud Schiller, Iconography of Christian Art. Vol. I. Christ's Incarnation - Childhood - Baptism - Temptation - Transfiguration - Works and Miracles (London, 1971, 1st German language print in 1966), p. 127, and the plates on pages 353-354; Gaston Duchet-Suchaux and Michel Pastoreau, The Bible and the Saints. Flammarion Iconographic Guides (Paris - New York, 1994), p. 172. 
Similarly, in late medieval art important preachers, and preaching scenes are often presented so that the dove is seen above the head of the preacher. For example, the famous Spanish Dominican preacher Vincent Ferrer is presented with a dove beside his right ear in Bartolomeo degli Erri's painting situated now in Seminario Metropolitano of Modena (formerly at the church of San Domenico in Modena). ${ }^{20}$

\section{Holy Spirit And the Audience}

As seen above the presence of the Holy Spirit was for the preachers themselves something that was taken for granted, or something that was necessary to be routinely evoked in the starting prayer of the sermon, or something that from time to time needed be reminded for the younger colleagues in connection with synodal sermons. In short, Holy Spirit's presence and effective intervention in the preaching was for the preachers self evident up to a point that it did not need to be reflected very often.

For the audiences the situation was different. As they were often reminded by the preachers, they were not only to listen to the sermons, but also to take heed of the message, suggestions, and warnings the preachers were uttering from the pulpit as the preaching was considered to be normative act of communication sanctioned by the Church. Not only that, but as we have seen above it was also an act including the Divine presence in the form of the Holy Spirit. For an ordinary member of congregation this normative and holy nature of the sermon was not something that was to be pondered too often. It was just the way it was, and thus the presence of the Holy Spirit in ordinary Sunday and Saint's day sermons was rather more likely latently accepted than actually recognised or actively thought by the parishioners.

However, things became very different when the ordinary parishioners came into contact with exceptionally talented or famous preachers. Their charismatic performances, often leading to more or less significant local religious revivals were often interpreted as work and influence of the Holy Spirit. Before I move into few exemplary cases one caveat is necessary; we do not have descriptions of the 'ordinary parishioners', but in most cases their reactions and opinions are available to us only as they were seen through the eyes of other members of clergy. Hence, it is quite possible that the reactions and opinions of the audiences were explained more theologically than they actually were.

An early example of a charismatic preacher whose preaching was interpreted by his contemporaries as Divinely inspired or even influenced was Saint Francis

20 This painting is reproduced in illustrative plate number 2 to Roberto Rusconi's article 'The Preacher Saint in Late Medieval Art' in Preacher, Sermon, and Audience in the Middle Ages. Edited by Carolyn Muessig. A New History of Sermon 3 (Leiden, 2002), pp. 181-200. 
of Assisi. His biographer Tommaso da Celano often points out that Francis was if not illiterate, at least idiota, namely he was not capable of reading and writing Latin on a level demanded from the priests. However, as Tommaso time after time describes, Francis was nevertheless capable of holding powerful sermons that effected not only the simple people, but also impressed the learned doctors and theologians, who were convinced that his preaching was Divinely inspired. Tommaso da Celano does not mention explicitly the Holy Spirit in connection with Francis' preaching, only when discussing the gift of foreseeing the future the saint had. However, Tommaso's descriptions of the mental and physical state of Francis when he was preaching give clear impression that it was the Divine Spirit who spoke through Francis. ${ }^{21}$

The Divine influence was strong according to Tommaso da Celano, that it made impossible for the listeners to remember what exactly Francis had said during his sermons. He writes in his second biography of Saint Francis: 'He did not use distinctions, for he did not invent or order his sermons himself. The true virtue and wisdom Christ gave the voice of virtue to his voice. Certain doctor of medicine who was learned and eloquent man said: "I can store to my memory other preacher's sermons word to word, only those that Saint Francis utters escape me. If I try to bear in mind some of those, it seems that what was first dropping from his lips is not meant for me." 22

While Tommaso da Celano's language here is poetically obscure, it seems clear that according to the testimony of the doctor, Francis' sermons were not to something to be listened and memorised, but rather to be experienced. It seems that not only Francis spoke under the Divine influence as in trance, but the same experience was shared by his audiences. Tommaso is thus in his own mystic and poetic way describing the extraordinary moment when charismatic preacher and his audience are united in strong emotional experience that cannot really be analysed afterwards.

Another interesting point is that Celano states that Jesus gave virtue to Saint Francis' voice ('Dabat voci suae vocem virtutis vera virtus et sapientia Christus'). This passage is clearly a quotation from the Psalm 67:34: 'who mounteth above the heaven of heavens, to the east. Behold he will give to his voice the voice of power (Lat. qui ascendit super caelum caeli a principio ecce dabit voci suae vocem fortitudinis')'. The only difference is that Tommaso da Celano has changed the word fortitudinis to the word virtutis, and that can be explained with contamination in the manuscript tradition.

21 I shall not list the well known cases of Francis' charismatic preaching here since they are quite well-known and easily found on the pages of his vitae; Analecta Franciscana. Tomus X. Legendae S. Francisci Assisiensis saeculis XIII et XIV conscriptae. (Firenze, 1926-1941), passim.

22 Tommaso da Celano, 'Vita seconda Sancti Francisci' in Analecta Franciscana. Tomus X. Legendae S. Francisci, p. 193-194. 
The very same Psalm quotation was used by another Franciscan, Salimbene de Adam ( $\dagger$ 1288) when he was describing the abilities of famous German Franciscan preacher Berthold von Regensburg ( $\dagger 1272)$ : 'And note that Brother Berthold had a specific grace from God when he was preaching. And all those who heard him say that from the times of the Apostles until our days, there has not been another one like him among the German speakers. He was followed by great masses of men and women, sometimes 60 or 100000 , sometimes the inhabitants of many towns came all together to listen the sweet and healing words that came from his mouth, by doing of Him, who [Ps. 67:34]: "gives to his voice the voice of power", and who [Ps. 67:12] "gives the word to them that preach good tidings with great power."' 23 The latter quotation we have seen above in connection with archbishop Federico Visconti who used it as a prothema on a synodal sermon dealing with preacher's office.

In case of Tommaso da Celano's anecdotes on Saint Francis' preaching, the connection between charismatic preaching and the influence of the Holy Spirit has to be read between the lines. For example, the same quotation from Psalm 67:34 that Tommaso da Celano used to describe Francis' preaching was half century later used to describe Berthold von Regensburg's preaching, and in the latter case there was no doubt that it was used to describe the Holy Spirit's intervention.

However, there are more explicit examples of the audiences attributing charismatic preacher's success to the Holy Spirit. One of the most striking cases is that of the Dominican preacher, blessed Ambrosio Sansedoni da Siena († 1286) who almost became saint on the strength of his charismatic preaching. ${ }^{24}$ Such an emphasis on the preaching was extremely rare in late medieval canonization processes. ${ }^{25}$

Our main source of the live preaching by Ambrosio Sansedoni is his Vita written on the authorisation of Pope Honorius IV. Since Honorius IV died in

23 Salimbene de Adam, Cronica. II a. 1250-1287. Editit Giuseppe Scalia. Corpus Christianorum. Continuatio Mediaevalis 125A (Turnhout, 1999), p. 840.

24 There is a Sermones de tempore collection attributed to Ambrosio(Siena, Bibl. Communale MS T.IV.7), but here we are more interested in actual delivery of his sermons than written model sermons he left behind and that (since they as far is known, exist only in one manuscript) were not particularly popular. Ambrosio's sermon collection is catalogued in J.B. Schneyer, Repertorium der lateinischen Sermones des Mittelalters für die Zeit 1150-1350 (Autoren: A-D). (Münster, 1969), pp. 280-286. It has been more throughly analysed by Tommaso Kaeppeli who dates it to the years 1273-1287; Tommaso Kaeppeli, 'Le prediche del B. Ambrosios Sansedoni da Siena', Archivum Fratrum Praedicatorum 38 (1968), pp. 5-12. For a short biography of Ambrosio, see Letizia Pellegrini, I manoscritti dei predicatori. Institutum Historicum Fratrum Praedicatorum Romae. Dissertationes Historicae, fasc. XXVI (Roma, 2000), p. 273.

25 Jussi Hanska, 'Saint Yves de Tréguier as a Preacher', Medieval Sermon Studies 49 (2005), pp. 29-31. 
1287, only year later than Ambrosio, it must be considered contemporary source, and indeed, the authors often claim to have been eye-witnesses for the events they chronicle. $^{26}$

The Vita claims that Ambrosio was modest, if not even shy, when it came to private discussions ('humilis et sermone privato aliquantulum pavidus'), but when he started to preach he became extremely courageous, especially when he was preaching on the sins, to the great wonder of those who knew him. In those occasions he had the spirit of prophecy and he preached filled with the fervour of the spirit and threatened the sinners in high places with imminent judgement of God unless they mend their ways. The biographers laconically state that the events later confirmed that he had been right in his predictions. ${ }^{27}$

Here the presence of the Holy Spirit is evident from the fact that Ambrosio received one of the gifts of Spirit, namely the capability of foreseeing future events or prophecy. The words used refer to the Holy Spirit but not in the clearest possible way: 'propheticae quoque spiritum habuisse', 'ex vehementi spiritus fervore'. However, the connection and explicit reference to the fact that his ways of preaching were totally uncharacteristic for him, confirm without doubt that his biographers took it that he preached under the direct influence of the Holy Spirit.

Another interesting point in this description is the change of personality in Ambrosio. When he was preaching he was behaving in un characteristic manner, or more likely, was not being himself. There is no need to read between the lines to observe this change in character, on the contrary, it has been practically underlined by the writers of the Vita who start their description of Ambrosio as preacher from noting this metamorphosis of a shy person to fiery preacher of penance. It seems that the writers of the Vita in this passage wanted to emphasise that Ambrosio was not preaching as himself, but either under the influence of the Holy Spirit or, indeed, so that the Holy Spirit actually preached with his mouth.

The biographers tell, mentioning that they know 'from trustworthy sources and most of all from brother Vincenzo da Arezzo, who was for a long time Ambrosio's disciple and companion' that Ambrosio was in the habit of digressing from the material he was preaching about and preaching something completely different. When this happened, he preached with such fervour of spirit and efficiency of words that he moved the audiences to great devotion and compunction of heart. ${ }^{28}$ Clearly then, when Ambrosio digressed from his original

26 Vita B. Ambrosii Senensi OP quam conscripserunt fr. Gisbertus, Alexandrinus, Recuperatus de Petramala, Aretinus, Aldobrandinus Paparonus, Oldradus Bis-dominus, Senenses ordinis predicatorum mandato domini Honorii IV Pontificis maximi. AA.SS. Martii, tomus tertius (Paris - Rome, 1865), pp. 180-209.

27 Vita B. Ambrosii Senensi, p. 191.

28 Ibid. 'A fide dignis accepimus, et praecipue a Fr. Vincentio Aretino, qui discipulus ejus et socius multo tempore fuit in praedicationibus, quod inter praedicandum pluries a materia de qua 
subject, he started to preach about sins and confession. Otherwise his audiences could not have been moved into compunction. The Vita gives the impression that such digressions were not planned, but Ambrosio was simply carried away by the Divine inspiration when preaching.

Brother Vincenzo da Arezzo had also testified to the writers of the Vita that he had seen twice when Ambrosio was preaching so much 'cum magno spiritu fervore' that he was elevated to the air when he spoke. Vincenzo was not the only one who had perceived this strange phenomenon, but the audiences had also seen it and started to shed tears and shout in chorus: 'Jesus, Jesus, our Lord'. Furthermore, the Vita continues, those present were positive that when Ambrosio was preaching they had seen a dove next to his ears. ${ }^{29}$

As stated above, the snow-white dove was the common iconographic symbol of the Holy Spirit. In fact, it was so common symbol, that it must have been known for Ambrosio's audiences also, and not only for the clerical authors of his Vita. If we are to believe the authors of the Vita, or more likely the testimony of Brother Vincenzo da Arezzo who was their primary source, we cannot but conclude that the audience perceived that Brother Ambrosio was preaching under the influence of the Holy Spirit. This incident became so famous that Ambrosio's own iconographic presentations often depict a Dominican brother with a dove at his ear, sometimes holding a model of Siena, sometimes holding a book or preaching. A good example is the famous Arliquiera painted by Lorenzo di Pietro better known as Il Vecchietta in 1445 and now housed in Pinacoteca Nazionale di Siena, or the works of baroque painter Francesco Vanni in several churches and public buildings in Siena.

Ambrosio Sansedoni was not the only preacher of whom such a story was told. On the fragments of canonization inquiry of blessed Gauthier de Bruges OFM. one of the witnesses testified that when Gauthier, by that time already bishop of Poitiers, was celebrating ordines generales, and the hymn Veni Creator Spiritus was sung, a dove appeared and started to circulate around his head. When the hymn ended the dove flew to the major altar and settled between two candles there. When the new priests were all anointed, the dove disappeared as mysteriously as it had arrived. ${ }^{30}$ While in case of Gauthier de Bruges, the appearance of the Holy Spirit was not connected with preaching, he nevertheless was a famous preacher. ${ }^{31}$

praedicabat digressionem faciebat, de alia praedicans materia, cum tanto spiritus fervore et verborum efficacia, quod audientes ad magnam devotionem et cordis contritionem commovebat.'

29 Ibid. ' Affirmabant autem praefati, columbam ad aures servi Dei Ambrosii se vidisse, dum praedicabat.'

30 André Callebaut, 'Recueil de miracles et preuves du culte immémorial de S. Gautier de Bruges O.F.M. évéque de Poitiers (1279-1306)', Archivum Franciscanum Historicum 5 (1912), p. 498-499.

31 See J.B. Schneyer, Repertorium der lateinischen Sermones des Mittelalters für die Zeit 1150- 
Thus Ambrosio Sansedoni's case is very similar to that of Saint Francis of Assisi with the exception that in Ambrosio's case the presence of the Holy Spirit is explicitly pronounced using the standard iconographic symbol. In both cases the audience perceives the preacher in a kind of trance or raptus, and in both cases the preacher manages to create a specific relationship that ties him to his audience in a sense that the listeners are particularly receptive to his preaching. In Ambrosio's case this particular reception is rhythmical shouting of Jesus' name. Similar incidents were later connected to Bernardino da Siena's brightest moments as popular preacher. For example, it was recorded by two independent witnesses, namely the reportator of the sermon and Paolo Tommaso Montauri, the writer of the Cronica Senese that when Bernardino was preaching at the Piazza del Campo in 1427 the whole audience started shouting rhythmically 'Jesus, Jesus, Jesus'. ${ }^{32}$ In both cases it seems obvious that the audiences thought that the exceptional charisma of the preachers was sure sign of the Divine inspiration and the Holy Spirit's presence in their sermon.

When dealing with the self perception of the medieval preachers we noted that Federico Visconti took the view that in extreme cases the Holy Spirit actually spoke with the mouth of the preachers. His examples concerned really what we might call proto-preachers, that is, the Old Testament prophets and King David. However, there are medieval sources where the Holy Spirit is perceived to speak with the mouth of contemporary preachers. One of the most interesting cases concerns Carmelite friar Saint Peter Thomas ( $† 1366)$, who is one of the few saints attributed with the gift of preaching.

His Vita tells us that when residing at the Papal curia in Avignon Peter Thomas was active preacher, and, perhaps unlike some others who did not want to upset Pope and the cardinals, he was vehement in his attacks against sin and sinners so that he 'spared no one, not Lord pope, nor anyone else.' His sermons, despite the fact that the audiences at the curia had seen and heard everything and were probably very hard to impress, often moved his audiences to tears or to laughter depending on what the saint wanted. At the end of his sermons, all the listeners went away with great consolation, because, as his biographer lets us know, the Holy Spirit spoke through his mouth. ${ }^{33}$

1350. Vol. 2 (Autoren: E-H). (Münster, 1970), pp. 103-108. Schneyer indicates a whole series of Sermones de tempore. These, however, are not by Gauthier. According to Jacques-Louis Bataillon, there are only three surviving sermons that can be attributed to Gauthier without doubt; JacquesLouis Bataillon, 'Gauthier de Bruges, Gauthier d'Aquitaine ou Fra Mattiolo', Medieval Sermon Studies 40 (1997), pp. 8-21.

32 Le prediche volgari di San Bernardino da Siena dette nella Piazza del Campo l'anno MCCCCXXVII. Ed. Luciano Bianchi, Vol. 2 (Siena, 1884), p. 184; Cronaca Senese di Paolo di Tommaso Montauri. Rerum Italicarum Scriptores, Tomus 15, part 6 (Bologna, 1937), c. 803.

33 Vita Sancti Petri Thomasio auctore Philippo Mazzerio. AA.SS. Januarii, Tomus 3 (Paris, 
Here we see a good example of biographer who claims that he believes that the Holy Spirit spoke through his saint. However, with hagiographic sources one cannot be sure that the text can be interpreted literally. In this particular case, the intervention of the Holy Spirit is introduced in a manner that makes one immediately think that it might be just a literary topos typical for the genre ('...quia spiritus sanctus, sicut pie credo, a juventute sua per os ejus loquebatur'). Nevertheless, even if one assumes that we are dealing with literary topos rather than sincere conclusion of the writer of the Vita, the very existence of such topos points to the direction that there was a custom to attribute particularly talented or effective preaching to the direct intervention of the Holy Spirit.

The fact that some preachers were seen to enjoy special favour and blessings of the Holy Spirit was not insignificant from the point of view of social and political life. It had a huge impact for the efficiency of the preacher in question. It was not the same who was preaching because some of the preachers were speaking to practically empty churches, or even had to lock the church doors before the sermon to keep the faithful in. Others could not speak inside the churches because they could not accommodate all the willing listeners.

It is generally known that during the Observant movement in the fifteenth century the most popular preachers, such as Bernardino da Siena ( $\dagger 1444)$, Giovanni da Capestrano ( $† 1456)$, or Bernardino da Feltre $(\dagger 1494)$, often had to deliver their sermons out in the town square. Their audiences were according to medieval sources measured in tens of thousands, but even taken into account the typical exaggeration of the chronicles, there were thousands of listeners. ${ }^{34}$ It is less well-known that the same phenomenon happened also during the preceding centuries. The most famous star preachers draw great masses to their sermons, and consequently they yielded great political power. For example, the German Franciscan preacher Berthold von Regensburg was in the habit of preaching on the field outside the towns so that there was enough space for all the listeners. He even had a flag on a high pole so that people could see the direction of the wind and take places in downwind where they could hear better. The reported numbers of his audiences were no smaller than those of the fifteenth-century Observant preachers. ${ }^{35}$

1863), p. 613. ' In praedicatione suae utique parcabat nulli, nec domino papae, nec quicumque. In medio vero sermonis communiter homines ridere faciebat, aliqua pulchra moralia narrando; modo flere, modo ridere faciebat; et in fine sermonis sui omnis homo a facie ejus aedificatus et consolatus recedebat: quia spiritus sanctus, sicut pie credo, a juventute sua per os ejus loquebatur, nec in sermonibus suis visus est spernere.'

34 For example, in connection of the above mentioned Sermon cycle of 1427 in Siena, the reporatio states that there were 30000 listeners at the Piazza del Campo, and Chronaca Senese gives even larger number of listeners; Le prediche volgari di San Bernardino da Siena dette nella Piazza del Campo l'anno MCCCCXXVII. p. 184; Cronaca Senese di Paolo di Tommaso Montauri. c. 803. Clearly these figures were exaggerated, but there is no reason to think that the audience would not have consisted of thousands.

35 Salimbene de Adam, Cronica. II, p. 840. 
Some of the most popular preachers had their own religious-political agenda that made them dangerous for some princes or city governments. For example, Bernardino da Feltre was known of his vehemently anti-Jewish sermons he delivered when promoting the mons pietatis institution. Therefore many rulers who had interests in defending the Jews against popular harassment were unwilling to let Bernardino to preach in their cities. However, Bernardino was not only famous trouble maker, but he was also known to pacify internal wars or skirmishes that were so typical for Italian city states at that time. When he was in Rome in 1486 Pope Innocent VIII personally thanked him for pacifying the city of Perugia with his sermons. ${ }^{36}$ The case of Girolamo Savonarola $(\dagger 1498)$ and the Medici family is perhaps the most well-known example of the influence preachers could wield and the risks rulers took allowing the most charismatic preacher's sermons in their cities.

\section{Conclusions}

It has been the position of the Christian church since the very beginning that office of preacher and skill to preach were spiritual gifts (on the New Testament Greek xápíouá) given by the Holy Spirit. Even if in the later Church one did not need to have visible Divine inspiration for clerical ordination, the underlying assumption that the Holy Spirit was present in preaching remained intact. For a long line of the preachers from the thirteenth century to the end of the middle ages (and indeed, beyond), the role of the Holy Spirit was self-evident and hence it was not reflected all that often.

When the issue came up, it often happened in occasions were preacher's were reflecting their own office and vocation, as it was case with the archbishop of Pisa and renowned preacher Federico Visconti. In these cases the conclusion was that fruitful and effective preaching was only possible due the inspiration provided by the Holy Spirit, and in any case, It's presence in legitimate and orthodox preaching was taken for granted.

The view point of the ordinary parishioners and the audiences of the preachers was somewhat different. While the preachers were generally accepted to praedicare verbum Domini and the preaching was perceived as more authoritative means of communication than ordinary speech, the role of the Holy Spirit comes generally into discussion only when it was question of exceptionally talented preachers or out of ordinary sermons. For them, not all the preachers had charisma or spiritual gift, but only those who were really on the top of their profession. Thus the Latin word charisma that for centuries had meant spiritual gift, started take the meaning it has in modern languages, namely a specific ability to communicate with the audiences some persons had and others not. 
The presence of the Holy Spirit manifested itself in different ways within the preaching of these exceptional preachers. Sometimes they managed to preach on the intellectual and theological level they did not possess in their ordinary discussions, sometimes they were seen to preach in a kind of trance or state of raptus, and sometimes small miracles happened during their preaching. In case of Ambrosio Sansedoni he was seen as floating in the air, and the snow white dove, the iconographic symbol of the Holy Spirit was seen next to his ear. In all the cases the exceptionally effective preaching that produced immediate results, such as masses or persons wishing to confess their sins, emotional reactions of the audience (crying, shouting, or singing), pyres of vanities, or small scale revival movements. Such results were not necessarily long lasting. Bernardino da Siena's status as Divinely inspired preacher was never questioned even if the small scale revivals and reform movements he originated were often as soon forgotten as he left the town.

Thus the main difference between the self-perception of the preachers themselves, and the understanding of their audiences seems to have been that the preachers accepted as self-evident fact that the Holy Spirit is always present in preaching situation provided that it is a question of sermon delivered by authorised preacher, and sanctioned by the Church. The audiences, on the other hand tended to see the Holy Spirit's intervention only in connection with the most talented and charismatic preachers. Here, however, it must be remembered that in most cases audience reactions are reported by the churchmen who perhaps were not so keen to register opinions of those who simply thought that preacher's success was due to his rhetorical skills, but rather emphasised more theologically acceptable explanations of Divine inspiration.

Thus, it is, and with the available sources will also remain unclear how large part of the audiences were agnostics who came to hear sermons for the entertainment value of good preachers and attributed their success to the simple fact that they were good speakers. Equally clear is, however, that the best of the preachers were able to provoke authentic revivalist religious reactions in their audiences, who, or at least part of them, truly believed that their sermons were manifest work of the Holy Spirit.

What then was the historical meaning of the perceived effect and presence of the Holy Spirit in the sermons of most talented preachers? The sermons of the such Divinely inspired preachers were certainly perceived to be more authoritative than those of their rank and file colleagues. They were no more just showcases of rhetoric but sanctioned from the highest possible authority. All the sermons were up to a some point political. At the very least the preachers were attempting to change the behaviour patterns of their audiences.

During the later middle ages, especially in the fifteenth century this political side of preaching, even in the traditional sense of the word politics, became 
increasingly important. By then the charismatic preachers were in increasing demand and cities competed fiercely of their services. On the other hand, such preachers were also often feared because they had the power to cause upheavals and riots. Sometimes this led to situations were important princes and the elders of the cities tried to keep certain charismatic preachers out of their realms or cities.

Thus, to sum it up, the perceived presence of the Holy Spirit in the sermons of a particularly talented preacher gave even more authority to his sermons. Some of the preachers, such as Observant Franciscan Bernardino Tomitano da Feltre did not hesitate the use this extra political weight to their own purposes. Even if the preachers did not consciously seek political power, their presence was nevertheless a factor that needed to be taken into account by the princes and councils of the cities. Depending on the situation and view point, the Divinely inspired preachers were either further asset for the rulers to help them to govern, or a threat to be dealt with. 
